\title{
CONSITUTIONAL QUESTION \\ (MENYOAL KONSTITUSIONALITAS PASAL TENTANG PENGEMIS KUHP PASAL 504 AYAT (1) DAN (2))
}

\author{
Isrok $^{1}$ \\ Abstrak
}

Human rights, as literated in constitution, described that "every people have the social rights which is make the people able to develop theirselves totally, as the dignity people". Besides, it is literated in the constitution, which is relating with the social prosperity, "poors and abandoned children are protected and cared by nation. The case abaut twelve jakarta's persons who being arrested, who give a gift to the beggars coordinators was chased and five beggar connectors arrested, then been judged are incidents that bring pro and contra in opinion. Judge, as one of four law enforcers, in judging same chase which is clearly literated in the constitution law norm (regulation) has to be the foundation in his decicion, the judge must discover, fallow and understand the value and justness sense in the society. But, if ther's same case that make the judge tesitate abaut the exiting regulation, then he may have a constitutional question. Constitutional question is the regulation testing which is dealing with same case, the constitutional question is needed to extend the supremacy of the law and peoples contitutional rights protection. Is same countries, like Germany, Croatia, Australia, and others countries, constitutional question is under the authority of constitutional court, what about in Indonesia?

\section{Kata kunci: CQ, HAM dan Mahkamah Konstitusi}

\section{Pendahuluan}

The end of Property adalah sebuah buku yang ditulis oleh Jeffrey D. Sachs tahun 2005 yang mengilhami Mohammad Yunus dengan Gramen Foundationnya, akhirnya meraih Nobel Perdamaian tahun 2006.

Konsep peraih Nobel ini mengatakan: Jangan memberi sedekah pada orang miskin, karena pemberian itu berarti merendahkan derajat dan tidak adaisrok@yahoo.com.

Dosen Fakultas Hukum Universitas Brawijaya. Alamat korespondensi: 
mendidik dalam arti tidak memberdayakan si miskin. Dikemukakan tiga hal untuk mengakhiri kemiskinan, yaitu: Menyediakan kesehatan dasar, memberikan pendidikan dan membangun infra struktur dalam hal penyediaan air, listrik serta komunikasi.

Menurut penulis pemberian sedekah kepada orang miskin diartikan dengan orang yang meminta-minta atau pengemis. Harian Kompas, dalam Tajuk Rencana "Pengemis dan Konstitusi", menurunkan berita sebagai berikut: ${ }^{2}$

Dinas Sosial Jakarta menangkap dua belas warga Jakarta yang memberikan sedekah kepada pengemis, mereka kemudian dijatuhi hukuman denda Rp. 150.000,- (Seratus lima puluh ribu rupiah) hingga Rp. 300.000,- (Tiga ratus ribu rupiah).

Pejabat Dinas Sosial DKI Jakarta berpendapat, sanksi denda itu diharapkan bisa memberikan efek jera kepada orang yang akan memberikan sedekah di jalanan, sedangkan sebanyak tiga puluh orang koordinator pengemis diburu dan lima penghubung ditahan.

Pejabat Dinas Sosial Jakarta itu berpendapat, jika tidak ada orang yang memberikan sedekah kepada pengemis jalanan, maka orang tidak akan mau menjadi pengemis. Larangan menjadi pengemis dan juga konstruksi legal bahwa memberikan sedekah adalah pelanggaran dilegalisasi dalam Peraturan Daerah Nomor 8 tahun 2007 tentang Ketertiban Umum. Dalam salah satu perda tersebut antara lain disebutkan, "Setiap orang atau badan dilarang menjadi pengemis, pengamen, pedagang asongan, dan pengelap mobil".

Akan tetapi yang menjadi pertanyaan, bukanlah orang mau menjadi pengemis karena ada orang yang mau memberi, atau bukankah orang menjadi pengemis karena mereka tak punya lagi sumber daya ekonomi sehingga terpaksa mengemis. Bukankah juga memberikan sedekah adalah wujud semangat untuk berbagi?

Tajuk Rencana itu selanjutnya melontarkan pertanyaan kritis. apakah ada orang yang memang ingin menjadi pengemis? Kita tidak ingin ada sebagian saudara kita menjadi pengemis dan meminta-minta. Kita berpendapat keinginan pemerintah yang hanya melarang orang menjadi pengemis dan menjatuhkan sanksi denda kepada orang yang memberikan sedekah, tanpa ada solusi apapun, bukanlah langkah bijak.

Pada dasarnya tidak ada orang ingin menjadi pengemis, mengemis adalah akibat dari keterpaksaan keadaan ketika mereka yang terpinggirkan itu tidak punya akses kepada sumber-sumber daya ekonomi, orang miskin

${ }^{2}$ Pengemis dan Konstitusi, Harian Kompas, tanggal 3 September 2009. 
tercipta juga karena kebijakan pembangunan yang kurang berpihak kepada mereka.

Jelas setiap orang berkeinginan hidup yang layak, dan secara konstitusional negara memberi jaminan untuk itu, hal ini dapat kita lihat ketentuan sebagai berikut: "Setiap orang berhak untuk hidup serta berhak mempertahankan hidup dan kehidupannya", dalam ketentuan lain UUD 1945 juga menyebukan: "Setiap orang berhak untuk hidup sejahtera lahir batin, bertempat tinggal dan mendapat lingkungan hidup yang baik dan sehat serta berhak memperoleh pelayanan kesehatan". Jaminan secara konstitusional seperti itu dapat diartikan apabila terdapat manusia, masyarakat yang hidup dengan meminta-minta jelas tidak sejalan dengan makna konstitusi yang ada.

Tindakan Dinas Sosial Jakarta itu menuai protes keras dari Lembaga Swadaya Masyarakat (LSM) khususnya yang membidangi masyarakat miskin, ada suatu alasan kuat yang menjadi dasar bagi LSM tersebut, yakni dasar Konstitusional. Dikemukakan adanya ketentuan, sebagaimana tercantum dalam Undang-Undang Dasar Negara RI Tahun 1945, secara jelas menyebutkan dalam pasal 34 ayat (1): "Fakir miskin dan anak-anak terlantar dipelihara oleh negara". Jadi negaralah yang sebenarnya bertanggungjawab terhadap fakir miskin. Mereka mengharapkan konstitusi sebagai wujud kontrak sosial bangsa ini dihormati, bukan malah sebaliknya.

Tindak lanjut ditahannya tiga puluh koordinator pengemis dan lima penghubung adalah proses pengadilan, dalam proses pengadilan terdapat suara protes keras dari LSM yang menaungi masyarakat terpinggirkan dan masyarakat miskin, yang intinya bahwa pasal tentang pengemis adalah tidak konstitusional.

Hakim yang akan mengadili para pengemis, termasuk koordinator dan penghubungnya, menjadi ragu dan bimbang dalam arti apakah produk hukum yang mengatur mengenai pengemis, sebagaimana diatur dalam KUHP masih konstitusional atau tidak (Constitusional Question, Pertanyaan Konstitusi).

Constitusional Question dapat diartikan sebagai pengujian suatu aturan hukum yang diajukan oleh hakim yang mengadili suatu perkara, di mana dalam suatu proses persidangan muncul pertanyaan tentang konstitusionalitas ketentuan aturan hukum yang akan digunakan dalam menilai sebagai dasar untuk mengambil suatu putusan.

Istilah constitusional question mengandung dua pengertian, umum dan khusus, dalam pengertian yang umum, constitutional question adalah istilah

${ }^{3}$ Undang-Undang Dasar 1945 bab XA tentang Hak Asasi Manusia, Pasal 28 A.

${ }^{4}$ Ibid., Pasal $28 \mathrm{H}$. 
yang merujuk pada setiap persoalan yang berkaitan dengan konstitusi (dan yang lazimnya merupakan kewenangan mahkamah konstitusi untuk memutuskannya. ${ }^{5}$

Sedangkan dalam arti khusus, constitutional question adalah merujuk pada suatu mekanisme pengujian konstiusionalitas undang-undang, di mana seorang hakim (dari regular courts) yang sedang mengadili suatu perkara menilai atau ragu-ragu akan konstitusionalitas undang-undang yang berlaku untuk perkara itu, maka ia mengajukan "pertanyaan konstitusionalitas" ke mahkamah konstitusi (mengenai konstitusionalitas tidaknya undang-undang itu) Mahkamah konstitusi hanya memutus persoalan konstitusionalitas undang-undang itu, jadi bukan memutus kasus itu sendiri, namun selama mahkamah konstitusi itu belum menyatakana putusannya, pemeriksaan terhadap kasus itu dihentikan. ${ }^{6}$

Mekanisme constitusional question diperlukan sebagai bagian dari upaya untuk menjamin tegaknya supremasi konstitusi dan perlindungan konstitusional terhadap warganegara yang ada. Dengan adanya mekanisme tersebut, maka akan diperoleh beberapa hal, yaitu:

1. Menghindari adanya putusan hakim yang bertentangan dengan konstitusi dengan demikian hak warga negara tetap terlidungi oleh konstitusi;

2. Bagi hakim akan lebih yakin bahwa apa yang sedang diadili benar-benar konstitusional;

3. Dalam proses constitusional question, utuk sementara perkara yang sedang diperiksa dihentikan, sehingga terdapat waktu untuk dipikirkan lebih lanjut akan kebenaran perkara yang sedang diperiksa.

Mengkaji constitusional question, kita tidak bisa melupakan perjalanan sejarah, sebagaimana dikemukakan oleh Abdul Hakim Garuda Nusantara ${ }^{7}$ "Sebuah tonggak sejarah baru dalam perkembangan ketatanegaraan Indonesia ialah dibentuknya Mahkamah konstitusi oleh Majelis

${ }^{5}$ Lihat misalnya Donald P. Kommers, 1989, "The Constitutional Jurisprudence of the Federal Republic of Germany", (Durham and London: Duke University Press. 1989), hal. 1 .

${ }^{6}$ Victor Ferreres Comelia, Is The European Model of Constitutional Review in Crisis, paper presented for the 12 th Annual Conference on, "The Individual Vs the State", Central European University, Budapest, June 18-19 2004 hal. 4.

${ }^{7}$ Abdul Hakim Garuda Nusantara, Mahkamah Konstitusi Perspektif Politik dan Hukum, Harian Kompas, tanggal 24 September 2002. 
Permusyawaratan Rakyat ketika melakukan perubahan Ketiga UUD 1945 ( 9 Nopember 2001). Dalam Pasal 2 ayat (2) UUD 1945 dinyatakan bahwa "Kekuasaan kehakiman dilakukan oleh sebuah Mahkamah Agung dan badan peradilan yang berada di bawahnya dalam lingkungan peradilan umum, lingkungan peradilan agama, lingkungan peradilan militer, dan lingkungan peradilan Tata Usaha Negara dan oleh sebuah Mahkamah Konstitusi. Ini berarti kekuasaan kehakiman menganut sistem bifurkasi bifurcation system), di mana kekuasaan kehakiman terbagi dua cabang, yaitu cabang peradilan biasa (ordinary court) yang berpuncak pada Mahkamah Agung dan cabang peradilan konstitusi yang mempunyai wewenang untuk melakukan constitutional review atas produk perundang-undangan yang dijalankan oleh Mahkamah Konstitusi".

Kembali kepada ketentuan pasal yang meragukan bagi hakim mengenai "pengemis", di mana secara normatif, dalam hal meminta-minta (mengemis), telah diatur dalam Kitab Undang-Undang Hukum Pidana (KUHP/Wetboek Van Straft Recht).

KUHP yang mengatur soal pengemis, disebutkan pada:

Pasal 504

Ayat 1

Barang siapa minta-minta (mengemis) di tempat umum dihukum karena minta-minta dengan hukuman selama-lamanya enam minggu.

Ayat 2

Minta-minta dilakukan bersama-sama tiga orang atau lebih, yang umurnya lebih dari 16 Tahun, dihukum kurungan selamalamanya tiga bulan.

Undang-undang peninggalan zaman kolonial Belanda, berupa Kitab Undang-Undang Hukum Pidana dan sudah lebih dari enam puluh tahun belum dirubah ${ }^{8}$ sehingga banyak aturan yang ada di dalamnya tidak sejalan dengan perkembangan hukum yang ada di masyarakat, bahkan tidak jarang terdapat ketentuan yang dianggap melanggar hak asasi manusia, seperti pasal yang berkaitan dengan kelalaian yang menyebabkan matinya orang yakni

\footnotetext{
${ }^{8}$ Tercatat dalam Kitab Undang-undang Hukum Pidana (KUHP), Peraturan Presiden RI tanggal 19 Oktober 1948.
} 
Pasal 359 KUHP, yang implementasinya sering merugikan orang yang disangka.

Hukum positif sebagaimana diuraikan di atas sifatnya imperatif dan berdasarkan teori positivisme menyebutkan bahwa keadilan itu lahir dari hukum positif yang di tetapkan manusia, dan hakim selaku penegak hukum terikat oleh teori ini, demikian Hans kelsen, Kelsen dalam hal ini menekanakan bahwa konsep keadilan itu mencakup pengertian yang jernih dan bebas nilai, dan hakim terikat dengan hukum positif yang ada berdasar paham legisme dalam konsep positivisme, hakim adalah corong Undangundang, dan hukum adalah perintah UU, sebagai konsep hukum yang ada benar-benar harus diterapkan.

Realita konsep positivisme dalam kaitannya dengan penegak hukum ternyata jauh dari rasa keadilan perkembangan hukum positif sangat ketinggalan dengan perkembangan masyarakat dan bangunan teknologi, sehingga dalam penerapan teori positivisme tidak serta merta dilaksanakan dengan paham legisme.

Sejalan dengan itu seorang pakar hukum mengatakan "Ilmu hukum sebagai sesuatu yang terus berubah, garis perbatasan ilmu hukum selalu bergeser, garis perbatasan ilmu pengetahuan selalu bergeser, lebih maju dan lebih maju", sejalan dengan ini Makaminam Makagiansar menyatakan:

Science eduacation should no limit itself to the transmission of when scientifiq displines and acquaint the leaner with the promise of frontier-science. $^{9}$

Tidak jauh berbeda adalah sebagaimana dikemukakan oleh Bryan Turner, ${ }^{10}$ bahwa ilmu hukum mengalami guncangan dan teori mengalami pergeseran fundamental. Munculnya banyak gagasan yang mendobrak gagasan lama secara perlahan tapi pasti memberikan pandangan alternative tentang hukum. Menurut Donny Gahral mereka (kaum postmodern) sebenarnya merupakan pewaris dari kaum sofis di Yunani yang sangat anti kebenaran tunggal, dan lebih mengedepankan kebenaran-kebenaran plural.

Dari uraian di atas maka beberapa catatan dari latar belakang dapat diuraikan secara singkat yaitu: Adanya hakim yang memeriksa perkara, akan

9 Makaminam Makagiansar, pidato dalam , Thrid Annual Meeting of Asean Acendemies of Science, Engineering and Technology and Similar National, July 8-9, 1999, Manila Philippnes.

9.

${ }^{10}$ Bryan Turner, "Teori-teori Sosiologis, Modernitas dan Modernitas", Op. Cit., hal. 
tetapi ragu-ragu akan konstitusionalitas pasal KUHP, berkaitan dengan perkara yang sedang ditangani/diperiksa, sehingga timbul pertanyaan konstitusi (constitusionalitas question), mengadili pengemis/koordinator pengemis, penghubung pengemis dirasakan berkaitan dan menyentuh hak asasi manusia, sebagaimana disebutkan dalam konstitusi Undang-Undang Dasar 1945, dan salah satu kekuasaan kehakiman yang berwenang memberi jawab/memberikan kata putus atas pertanyaan konstitusi adalah Mahkamah Konstitusi untuk negara di luar Indonesia, yang selama ini dilakukan oleh negara Jerman, Australia, Kroasia dan negara lainnya.

\section{Permasalahan}

Berangkat dari uraian di atas, di mana hakim mengalami keraguan atas ketentuan norma hukum yang ada, maka permasalahan yang timbul adalah:

1. Apakah dapat dimasukkan dalam teori Constitutional Question (Pertanyaan Konstitusi), ketentuan norma hukum tentang pengemis dalam pasal 504 ayat (1) dan (2) KUHP yang akan dipergunakan hakim sebagai dasar untuk menilai putusannya?

2. Apakah Mahkamah Konstitusi di Indonesia dalam hal ini berwenang terhadap Constitutional Question?, yang diajukan hakim yang sedang menangani perkara.

\section{Pembahasan}

\section{A. Indonesia adalah Negara Hukum}

Dimaksudkan negara hukum adalah, bahwa segala sesuatu berdasarkan hukum dan hukum adalah supremasi, sejalan dengan negara hukum Ni'matul Huda" mengemukakan "Undang-Undang Dasar Negara Republik Indonesia tahun 1945 menegaskan bahwa Indonesia adalah negara hukum, prinsip ini semula dimuat dalam Penjelasan, yang berbunyi "Negara Indonesia berdasar atas hukum (rechtsstaat) tidak berdasar atas kekuasaan belaka (machtsstaat).

11 Ni'matul Huda, Perkembangan Peran Mahkamah Konstitusi Dalam upaya menegakan Hukum dan Keadilan, disampaikan dalam acara Seminar Sehari, "Mekanisme Constitutional Question Sebagai Sarana Menjamin Supremasi Konstitusi", Diselenggarakan oleh Pusat Pengkajian Konstitusi Fakultas Hukum Universitas Brawijaya kerjasama dengan Sekretariat Jenderal dan Kepaniteraan Mahkamah Konstitusi RI, Malang 21 November 2009. 
Materi penjelasan tersebut kemudian diangkat ke dalam pasal 1 ayat (3) UUD 1945 (Perubahan Ketiga) berbunyi "Negara Indonesia adalah Negara Hukum", istilah rechtsstaat tidak lagi dimuat dalam UUD 1945. Demikian pula tentang kekuasaan kehakiman yang mandiri, diangkat dari Penjelasan menjadi materi muatan UUD 1945 Pasal 24 ayat (1). Hal ini akan lebih menguatkan konsep negara hukum".

Mengkaji negara hukum umumnya dikaitkan dengan fungsi hukum, dalam hal ini terdapat empat fungsi dasar hukum, yaitu: ${ }^{12}$

1. Menetapkan hubungan antara anggota masyarakat, dengan menunjukkan jenis-jenis tingkah laku apa yang diperkenankan dan apa pula yang dilarang,

2. Menentukan pembagian kekuasaan dan merinci siapa-siapa yang boleh secara sah menentukan paksaan serta siapa yang harus mentaatinya dan sekaligus sanksi-sanksinya yang efektif,

3. Menyelesaikan sengketa yang ada,

4. Memelihara kemampuan masyarakat untuk menyesuaikan diri dengan kondisi-konsidi kehidupan yang berubah, dengan merumuskan kembali hubungan antara para anggota masyarakat itu.

Demikian pula mengkaji negara hukum tidak terlepas dengan penegakan hukum yang jelas terkait dengan sistem hukum yang ada, sebagaimana Friedman ${ }^{13}$ mengatakan bahwa sistem hukum meliputi: Pertama, Struktur hukum (Legal structure), yaitu bagian-bagian yang bergerak di dalam suatu mekanisme sistem atau fasilitas yang ada dan disiapkan dalam sistem, misal: Pengadilan, kejaksaan, Kedua, Substansi hukum (Legal substance), yaitu hasil aktual yang diterbitkan oleh sistem hukum, misal putusan hakim, undang-undang, Ketiga, budaya hukum (Legal culture), yaitu sikap publik atau nilai-nilai, komitmen moral dan keasadaran yang ada di masyarakat.

\section{B. Putusan Hakim yang Adil}

Hakim sebagai pelaku penegakan hukum mengemban amanah dengan tugas yang mulia dan penuh tanggungjawab baik terhadap

${ }^{12}$ Edwin M. Schur, "Law and Society, A Sociological Perspectif", (Random House: New York, 1968), hal. 78-82.

${ }^{13}$ Lawrence M. Friedman, "The Republic of Chice, Law, Authority, and Culture", (Harvard University Press, 1990), tanpa nomor halaman. 
sesamanya terlebih di hadapan Allah SWT, dan adanya adagium "Fiat justitia et pereat mundung ruat coulum" yang artinya, "Meskipun dunia akan runtuh hukum harus ditegakkan" selalu menjadi acuhannya.

Keadilan yang paling besar adalah pemenuhan keinginan sebanyak-banyaknya orang, sampai dimanakah batasan tingkat pemenuhan tersebut agar dapat memenuhi kebahagiaan sehingga layak disebut keadilan? Pertanyaan tersebut tidak dapat dijawab berdasarkan pengetahuan rasional, jawaban pertanyaan tersebut adalah suatu pembenaran nilai (a judgement of value), yang ditentukan oleh faktor emosional dan tunduk kepada karakter subyektif sehingga bersifat relatif. A judgment of value adalah pertanyaan dimana sesuatu dideklarasikan sebagai suatu tujuan, statement semacam itu selalu ditentukan oleh faktor emosional.

Suatu sistem nilai positif tidak diciptakan secara bebas oleh individual tersendiri, tetapi selalu merupakan saling mempengaruhi antar individu dalam suatu kelompok. Setiap sistem moral dan ide keadilan merupakan produk masyarakat dan berbeda-beda tergantung pada kondisi masyarakatnya. Fakta bahwa terdapat nilai-nilai yang secara umum diterima oleh masyarakat tertentu tidak bertentangan dengan karakter subyektif dan relatif dari pembenaran nilai. Demikian pula halnya dengan banyaknya persetujuan individu tehadap pembenaran tersebut tidak membuktikan bahwa pembenaran tersebut adalah benar. Hal ini sama dengan fakta bahwa banyaknya orang percaya matahari mengelilingi bumi tidak dengansendirinya membuktikan kebenarannya.

Seorang hakim dalam putusannya selain menuangkan suara nurani keadilan juga putusannya selalu menimbulkan dua opini. Hakim sebagai inti pelaku penegakan hukum, dapat mengkomunikasikan kekuatan ilmiah dan empirisnya dalam bentuk tulisan, karena putusan hakim memang harus mengandung pertimbangan ilmiah, yuridis, logis, faktual, dan nilai-nilai yang hidup sebagai bagian kekuatan dalam masyarakat. Secara yuridis formal, pada saat putusan hakim dibacakan, diucapkan dan diketukkan palu sidang dalam suasana persidangan untuk umum, maka fungsi pers atas putusan tersebut telah melekat dan menjadi hak publik yang dapat diketahui umum yang harus diberikan oleh pengadilan melalui layanan publik tersedia. Ketika kepastian keadilan hukum, kebenaran, dan prinsip kebebasan hakim dikemas tulisan, maka sat itu seorang hakim telah berjuang dengan mengangkat pena menuangkan suara nurani keadilan ke mukia bumi ini, dan dunia akan bergetar mengalami perubahan. 
Begitu besar makna nilai suatu putusan, lebih-lebih kalau suatu perkara menjadi perhatian publik, maka putusan seorang hakim harus benar-benar extra hati-hati karena pasti akan terdapat dua opini atas putusan tersebut yaitu putusan dipuji atau dicaci maki. ${ }^{14}$

Hal ini sesuai dengan apa yang diucapkan oleh Ketua Mahkamah Agung. ${ }^{15}$ Tetapi yang sering menjadi sorotan adalah apabila hakim memutar balikkan fakta atau hakim terlalu formalistis, yang mengakibatkan terdakwa dibebaskan, oleh karena itu para pimpinan pengadilan dituntut untuk selalu memberikan bimbingan dan mendiskusikan masalah-masalah hukum yang ada, dengan memperhatikan rasa keadilan yang berkembang di tengah-tengah masyarakat, menurut pengalaman di dalam menangani kasus yang besar dan menarik perhatian masyarakat, maka apapun yang diputuskan oleh hakim selalu terbelah dalam dua opini, apabila hakim memutus dengan melakukan ijtihad, ia akan dipuji sebagai hakim yang pemberani, akan tetapi akan dicaci maki oleh golongan yang bersifat legalistik. Apabila hakim hanya memutus dengan dasar aturan-aturan formal, maka ia akan dicap sebagai hakim yag berjiwa penakut karena hanya menggantungkan diri pada kepastian. Dalam hal keadilan sejarah membuktikan bahwa dambaan masyarakat sejak dahulu adalah keadilan, peristiwa di bawah ini dapat kita jadikan catatan

\section{Keadilan versi Socrates}

Tahun 400-an SM kehidupan politik di Yunani diwarnai segala macam kezaliman, penguasa kerap bertindak sewenang-wenang, para politisi banyak yang korup. Mereka bekerja lebih untuk kepentingan pribadi, di tengah suasana kebathinan yang buruk, para filsuf berjuang keras untuk menyebarluaskan kebajikan di kalangan rakyat.

Socrates, berucap bahwa tugas negara adalah menciptakan hukum, dan ini harus dilakukan oleh para pemimpin atau para penguasa yang dipilih secara seksama oleh rakyat. Socrates selalu menolak dan menentang keras apa yang dianggapnya bertentangan dengan ajarannya yaitu "mentaati undang-undang". ${ }^{16}$

${ }^{14}$ Tim Redaksi Ikatan Hakim Indonesia, Varia Peradilan, Majalah Hukum, tahun XXV No.228 November 2009, hal. 4.

${ }^{15}$ Mahkamah Agung RI, Sambutan Penutup Rakernas Ketua MA tgl 10 Oktober 2009 di Palembang, 8). Ikatan Hakim Indonesia, Varia Peradilan, Majalah Hukum, Tahun XXV No.228 November 2009, hal. 9. 
Dengan demikian kepatuhan terhadap hukum bagi Socrates sangat dijunjung tinggi, akan tetapi ajaran yang mendidik murid-muridnya untuk menjadi pandai, berani untuk kebenaran, pada saat itu di anggap merusak alam pikiran anak-anak muda, dan Khotbah-khotbahnya dianggap melawan kebijaksanaan penguasa serta meracuni pikiran rakyat yang akhirnya Socrates ditangkap dan diadili.

Sebelum masuk penjara, di muka para pengadil ia berkata: "Tuantuan kekuasaan yang ada pada tuan-tuan dapat membuat hukum semaunya, tetapi kekuasaan tuan-tuan pada akhirnya akan dikalahkan oleh perasaan keadilan rakyat yang tidak dapat dimatikan atau ditindas. Lama setelah saya nanti mati, tuan-tuan sebagai hakim akan dikenal sebagai contoh-contoh, di mana hukum tidak sama dengan keadilan, hukum datang dari otak manusia, sedangkan keadilan datang dari hati sanubari rakyat.

Selama di tahanan menunggu pelaksanaan eksekusi - Socrates mendapat kunjungan dari banyak teman yang merasa simpati dan berusaha keras menyelamatkan nyawanya, satu saat terjadi percakapan di penjara antara Socrates, Glaucan dan Tharsymachus, masalahnya keadilan menjadi tema sentralnya. Menurut Tharsymachus kehidupan orang yang menginjak-nginjak keadilan (The Unjust) ternyata lebih bahagia dari pada mereka yang menegakkan keadilan (The Just), bukan hanya itu Perfect justice is more gainful than perfect juctice, kilah Tharsymachus mencoba meyakinkan pada Socrates, intinya The Just kian tersudut dalam masyarakat dikalahkan oleh yang zalim.

Dengan gayanya yang khas dan tenang Socrates berusaha merubah pikiran Tharsymachus. Untuk sementara The Unjust memang unggul dalam peraturangan dengan The Just, mereka tampak bahagia dan bebas, orang yang menegakkan keadilan dan menempuh jalan lurus diakui oleh Socrates sering dilecehkan oleh masyarakat. Namun kita tidak boleh berhenti sampai di situ, yang namanya keadilan tidak boleh di kompromikan, sebab keadilan merupakan suatu kebijakan, sedangkan ketidak adilan merupakan tindak kriminal, pada saatnya nanti jawab Socrates, percayalah The Unjust akan mendapatkan hukuman dari alam, sebaliknya The Just akan memperoleh apa yang menjadi haknya.

Yang tidak kalah hebat adalah pendirian Socrates bahwa keadilan tidak selalu dicerminkan oleh penguasa. Keadilan adakalanya justru datang dari rakyat jelata, dari pihak yang dikuasai, jika penguasa

${ }^{16}$ Soehino, "Ilmu Negara", (Yogyakarta: Liberty, 1980), hal. 14. 
berbicara tentang keadilan maka sebenarnya yang terjadi adalah ketidak adilan atau kebatilan.

\section{Contitusional Question dalam Kasus}

Kasus hukum yang pernah muncul dan terkait dengan Contitusional Question, adalah kasus Z.M yang diajukan ke pengadilan dengan dakwaan mencermarkan nama baik Presiden SBY. Terdapat pendapat berbeda dengan pasal yang diterapkan dan timbul kontroversi, karena pasal-pasal KUHP yang dijadikan dasar dakwaan itu menimbulkan perdebatan, apakah pasal-pasal itu Konstitusional.

Seandainya Mahkamah Konstitusi memiliki kewenangan untuk memberi jawaban,maka hakim yang menangani perkara tersebut dapat bertanya lebih dahulu kepada Mahkamah Konstitusi tentang konstitusionalitas pasal tersebut sebelum menjatuhkan putusan. ${ }^{17}$

Dalam pasal penghinaan tersebut, ketentuan Pasal 134 berbunyi sebagai berikut: "Penghinaan dengan sengaja terhadap Presiden atau Wakil Presiden dihukum dengan hukuman penjara selama-lamanya enam tahun atau denda sebanyak-banyaknya Rp.4.500".

1. pasal ini mengancam pula hukuman pada "penghinaan dengan sengaja" terhadap Presiden atau Wakil Presiden. Yang diartikan dengan "penghinaan dengan sengaja" yaitu perbuatan mengancam apapun juga yang menyerang nama baik, martabat atau keagungan Presiden atau Wakil Presiden, termasuk segala macam penghinaan yang tersebut dalam bab XVI Buku ke II KUHP yaitu pasal 310 s/d 321, seperti menista (smaad), menista dengan surat (smadscrift), memfitnah (laster), penghinaan ringan (eenvoudige beleding), dan tuduhan memfitnah (lasterlijk aanklacht).

2. orang yang menghina itu harus mengetahui, bahwa ia berhadapan dengan Presiden atau Wakil Presiden. Penghinaan yang dilakukan terhadap orang yang oleh penghina tidak diketahui. Bahwa orang itu Presiden atau Wakil Presiden, tidak masuk pasal ini ,akan tetapi masuk penghinaan yang diancam hukuman (bab XVI buku ke II).

3. penghinaan terhadap orang biasa umumnya tidak dapat dituntut, bila tidak ada pengaduan dari orang yang dihina (delik aduan),

17 Machfud MD, disampaikan dalam acara Seminar Sehari, "Mekanisme Constitutional Question Sebagai Sarana Menjamin Supremasi Konstitusi", Diselenggarakan oleh Pusat Pengkajian Konstitusi Fakultas Hukum Universitas Brawijaya kerjasama dengan Sekretariat Jenderal dan Kepaniteraan Mahkamah Konstitusi RI, Malang 21 November 2009. 
akan tetapi penghinaan terhadap Presiden harus di tuntut dengan tidak perlu ada pengaduan dari jang dihina.

4. Semua alat negara yang diwajibkan untuk mencari dan menuntut perkara, karena jabatannya itu wajib menuntutnya.

5. lihat pula pasal 136 bis.

Kasus lain yang berkaitan dengan Constitutonal Question, Machfud M.D, dalam salah satu seminar menyampaikan tulisannya berkaitan dengan kasus Constitutional Question. ${ }^{18}$ Ada contoh aktual lain tentang ini. Pada saat Mahkamah Konstitusi sedang menangani pengajuan Pasal 23 Ayat (1) UU No.4 Tahun 2004 tentang kekuasaan kehakiman yang pengujiannya diminta oleh Polycarpus Budihari Priyanto, peninjauan kembali dia yang sudah, maka Polycarpus mengajukan permohonan Judicial Review ke MK agar isi UU No.4 Tahun 2004 dinyatakan inkonstitusional dan tidak mempunyai kekuatan hukum mengikat, padahal seumpama permohonan itu dikabulkan dan Pasal 23 Ayat (1) UU No.4 Tahun 2004 itu dibatalkan oleh Mahkamah Konstitusi tetaplah tidak akan ada pengarunya bagi hukuman yang harus di jalani oleh Polycarpus; artinya ia tidak harus tetap menjalani hukuman seperti putusan Peninjauan Kembali dari Mahkamah Agung. Seperti diketahui putusan Mahkamah Konstutusi tentang Judicial Review berlaku Prospektif (ke depan) dan tidak bisa membatalkan putusan Mahkamah Agung karena hal ini bukanlah wewenang Mahkamah Konstitusi oleh sebab itu perasaan atau anggapan Polycarpus bahwa vonis Peninjauan Kembali dari Mahkamah Agung itu telah melanggar hak Kontitusionalnnya lebih lanjut diselesaikan melalui Constitutional Complaint, maka masalahmasalah tersebut tetap belum dapat diajuakan ke Mahkamak Konstitusi atau jalan penyelesaian hukum yang lain, itulah sebabnya menjadi penting agar dipikirkan kemungkinan menambah kewenagan Mahkamah Konstitusi untuk memutus Constitutional Complaint agar pelanggaran-pelanggaran hak konstitusional yang tidak ada jalur penyelesaian hukumnya dapat ditangani oleh Mahkamah Konstitusi.

Pasal lain dalam KUHP yang sering merugikan seseorang yang tidak bersalah, akan tetapi karena ada korban yang meninggal, maka yang hidup dalam perkara terkait dapat dipastikan dianggap bersalah.

Pasal 359 


\begin{abstract}
Barang siapa karena salah menyebabkan matinya orang dihukum penjara selama-lamanya lima tahun atau kurungan selama-lamanya satu tahun. (KUHP. 165-2e, 187 $s, 193-205,334)$.
\end{abstract}

1. Mati orang disini tidak dimaksud sama sekali oleh terdakwa, akan tetapi kematian tersebut hanya merupakan akibat dari pada kurang hati-hati atau lalainya terdakwa (delik culpa), misalnya seseorang sopir menjalankan kendaraan mobil terlalu kencang, sehingga menubruk orang sampai mati, atau orang berburu melihat sosok hitam-hitam dalam tumbuh-tumbuhan, dikira babirusa terus di tembak mati, tetapi ternyata sosok yang dikira babi itu adalah manusia, atau orang main-main dengan senjata api, karena kurang hati-hati meletus dan mengenai orang lain sehingga mati dan sebagainya. Apabila mati orang itu dimaksud oleh terdakwa, maka ia dikenakan pasal tentang pembunuhan (Pasal 338 atau 340).

2. "Karena sengaja" = kurang hati-hati, lalai, lupa, amat kurang perhatian. ${ }^{19}$

D. Apakah Dapat Dimasukkan dalam Teori Constitutional Question (Pertanyaan Konstitusi), Ketentuan Norma Hukum tentang Pengemis dalam pasal 504 ayat (1) dan (2) KUHP yang akan Dipergunakan Hakim sebagai dasar untuk Menilai Putusannya?

Untuk menganalisa atas permasalahan ini, diperlukan terlebih dahulu pemahaman tentang Constitutional Question.

Pertama, yang berkaitan dengan sejarah kelahiran Constitutional Question.

Sejarah kelahiran constitutional question tidak terlepas dari sejarah kelahiran mahkamah konstitusi. Sebagaimana diketahui, ide membentuk mahkamah konstitusi mula pertama di gagas oleh Hans Kelsen setelah berakhirnya perang dunia I, yang antara lain diikuti oleh runtuhnya Kekaisaran Austro-Hungaria dan berdirinya Republik Austria. Di republik yang baru di bentuk ini Hans Kelsen diangkat menjadi Chancelery yang bertugas menyusun Konstitusi Austria $(1919-1920)^{20}$

19 Perkara dengan tuduhan Pasal 359 KUHP berdasarkan catatan penulis, tidak dilanjutkan dengan putusan hakim, dan adakalanya diselesaikan dengan musyawarah, hal ini bertentangan dengan norma yang ada. 
Disinilah Kelsen mengemukakan gagasannya tentang perlunya Austria memiliki mahkamah konstitusi (yang terpisah dari sistem peradilan biasa) yang fungsinya adalah untuk menegakkan konstitusi dengan kewenangan utama membatalkan undang-undang jika undangundang itu bertentangan dengan konstitusi. ${ }^{21}$ Dengan demikian, fungsi mahkamah konsitusi adalah melaksanakan Consitusional Quesion. ${ }^{22}$

Sedangkan Constitutional review - yang merupakan produk system pemerintahan modern yang dilandasi oleh gagasan Negara hukum (rule of law), pemisahan kekuasaan (separation of powers), dan perlindungan terhadap hak asasi manusia (Protection of fundamental rights) - memiliki dua tugas utama. Pertama, menjaga berfungsinya proses-proses demokrasi dalam hubungan saling mempengaruhi antara lembaga legislatif, eksekutif, dan yudikatif. Dengan kata lain, Constitutional review bertugas mencegah perebutan kekuasaan oleh salah satu cabang kekuasaan Negara dengan mengorbankan cabang-cabang kekuasaan Negara lainnya. Kedua, yang tidak kalah pentingnya dan berkait dengan erat dengan tugas pertama itu, adalah untuk melindungi hak-hak atau kehidupan pribadi warga Negara dari pelanggaran yang dilakukan oleh salah satu cabang kekuasaan Negara. ${ }^{23}$

Kedua, yang berkaitan dengan makna Constitutional Question.

Constitutional Question adalah pertanyaan Konstitualitas aturan hukum yang akan digunakan dalam menilai sebagai dasar putusan oleh seorang hakim, demikian dijelaskan Machfud MD.

Sebagaimana makalah yang dikemukakan oleh I Dewa Gede Palgunadi dalam seminar Nasional, bahwa istilah Constitutional

${ }^{20}$ Lihat Herbert M. Kritzer (ed), "Legal Systems of the World, A Political, Social and Cultural Encyclopedia”, volume I: A-D, (New Delhi: Pentagon Press, 2005), hal. 93. Jimly Asshiddiqie, "Model-Model Pengujian Konstitusional Di Berbagai Negara", Cetakan Kedua, Konpres: Jakarta, 2005), hal. 34; Herman Schwartz, "The Strungle for Constitutional Justice in Past-Communist Europe", (Chicago and London: University of Chicago Press, 2000), hal. 17; Mauro Cappelletti, "The Judicial Process in Comparative Perspective", (Oxford: Clarendon Press, 1989), hal. 136; Michael green, "Hans Kelsen and The Logic of Legal System ", dalam Alabama Law Review, Volume 54, Number 2, Winter 2003, hal. 385.

${ }^{21}$ Herman Schwartz, Loc. Cit.

${ }^{22}$ Lebih jauh mengenai pasang-surut perkembangan gagasan tentang konstitutional review ini, lihat, antara lain, Jimly Asshiddiqie, 2005, "Model-Model Pengujian Konstiusional", Op. Cit., hal.1-7.

${ }^{23}$ H. Hausmaninger, "The Austrian Legal System", (Manzsche Verlags- und Universitatsbuchhandlung, 2003), hal.139. 
Question mengandung dua pengertian, umum dan khusus, dalam pengertian yang umum, constitutional Question adalah istilah yang merujuk pada setiap persoalan yang berkaitan dengan konstitusi, yang lazimnya merupakan kewenangan Mahkamah Konstitusi untuk memutusnya. ${ }^{24}$

Sedangkan dalam arti khusus, pengertian, constitutional question adalah merujuk pada suatu mekanisme pengujian konstitusionalitas undang-undang dimana seorang hakim (dari reguler courts) yang sedang mengadili suatu perkara menilai atau ragu-ragu akan konstitusionalitas undang-undang yang berlaku untuk perkara itu, maka ia mengajukan'pernyataan konstitusional' ke mahkamah konstitusi (mengenai konstitusional - tidaknya undang-undang itu). Mahkamah konstitusi hanya memutus persoalan konstitusionalitas undang-undang itu, jadi bukan memutus kasus itu sendiri, namun selama mahkamah konstitusi belum menyatakan putusannya, pemeriksaan terhadap kasus tersebut dihentikan. ${ }^{25}$

Dalam KUHP telah telah disebutkan pada Pasal 504 ayat (pasal pengemis):

1. Barang siapa minta-minta (mengemis) di tempat umum dihukum karena minta-minta, dengan hukuman selama-lamanya enam minggu;

2. Minta-minta yang dilakukan bersama-sama tiga orang atau lebih, yang umurnya lebih dari 16 tahun, dihukum kurungan selamalamanya tiga bulan.

Terdapat catatan di bawah buku KUHP tersebut, yang isinya sebegai berikut:

1. Larangan ini sedikitnya janggal dalam masyarakat Indonesia yang biasa berzakat memberi pada fakir miskin. Larangan ini seolaholah a sosial, akan tetapi bukan itu yang dimaksud. Pasal ini bukan melarang kepada orang miskin yang "minta pertolongan" akan tetapi melarag melakukan perbuatan itu di tempat umum, misalnya di pasar, di station, tepi jalan dsb, karena perbuatan itu selain dapat mengganggu pada orang-orang yang sedang

${ }^{24}$ Lihat misalnya Donald P. Kommers, "The Constitutional jurisprudensi of the Federal Republic of Germany", (Durham and London: Duke University Press, 1989), hal. 1.

${ }^{25}$ Victor Ferreres Comella, Is the Eropean Model of Constitutional Review in Crisis, paper presented for the $12^{\text {th }}$ Annual Conference on 'the Individual Vs. the State', Central Eropean University, Budapest, June 18-19, 2004, hal. 4. 
bepergian pun dilihat kurang pantas dan amat memalukan. Jika datang ke rumah orang untuk memintanya, tidak dikenakan pasal ini, asal tidak kelihatan di jalan umum.

2. Minta-minta atau mengemis = dapat dilakukan dengan meminta secara lisan, tertulis atau dengan memakai gerak-gerik. "Menjual" lagu-lagu dengan jalan menyanyi, main biola, gitar, angklung, seruling, musik dsb. Menyodorkan permainannya sepanjang tokotoko dan rumah-rumah yang biasa dilakukan di kota-kota besar, dapat masuk dalam pengertian "mengemis".

Keraguan hakim yang memeriksa perkara ini antara lain, satu sisi hakim melihat bahwa pengemis secara normatif, sebagaimana tercantum dalam KUHP, Fatwa Majelis Ulama Indonesia (MUI) dilarang mengatakan bahwa pengemis adalah haram, dalam ajaran agama disebutkan bahwa tangan di atas lebih mulia daripada tangan yang di bawah, peraih nobel Mohammad Yunus menyarankan untuk memberdayakan si miskin dan tidak boleh memberikan sedekah agar derajat dan martabatnya terjaga sehingga ada usaha untuk selalu berusaha, tetapi dilain fihak peduli sesamanya diperlukan dalam proses kehidupan beragama, bahkan secara konstitusional Undang-Undang Dasar Negara RI Tahun 1945, menyebutkan dalam pasal 34 ayat (1) “ Fakir miskin dan anak-anak terlantar dipelihara oleh negara".

Keraguan hakim yang memeriksa perkara ini kemudian memunculkan suatu pertanyaan konstitusi berupa apakah norma hukum sebagai dasar untuk memutus perkara, berupa pasal dalam KUHP konstitusional atau tidak (Constitutional Question) dan pertanyaan konsitusi inilah yang dicari jawabannya oleh hakim tersebut.

Uraian di atas bila ditemukan dengan teori Constitutional Question, yang dikemukakan oleh Victor Ferreres Comella dalam Is The European Model Constitutional Review in Crisis adalah tepat, dan termasuk dalam Constitutional Question dalam arti khusus.

Berikutnya adalah mengenai permasalahan:

Apakah Mahkamah Konstitusi di Indonesia dalam hal ini berwenang terhadap Constitutional Question?, yang diajukan hakim yang sedang menangani perkara.

Untuk menganalisa permasalahan ini, harus dilihat kewenangan yang ada pada Mahkamah Konstitusi.

Secara konstitutional sebgaimana disebutkan dalam pasal $24 \mathrm{C}$ Ayat (1), dan (2)yang bunyinya: 
(1). Mahkamah Konstitusi berwenang mengadili pada tingkat pertama dan terakhir yang putusannya bersifat final untuk menguji undang-undang terhadap Undang-Undang Dasar, memutus sengketa kewenangan lembaga Negara yang kewenangannya diberikan oleh Undang-Undang Dasar, memutus pembubaran partai politik, dan memutus perselisihan tentang hasil pemilihan umum. (hasil perubahan ketiga)

(2). Mahkamah Konstitusi wajib memberikan putusan atas pendapat Dewan Perwakilan Rakyat mengenai dugaan pelanggaran oleh Presiden dan/atau Wakil Presiden menurut Undang-Undang Dasar. (Hasil perubahan ketiga)

Sejak keluarnya UU No.12 Tahun 2008 yang merupakan perubahan atas UU No.12 Tahun 2004 kewenangan Mahkamah Konstitusi di tambah satu lagi yakni memeriksa dan memutus sengketa hasil pemilihan Kepala Daerah (PILKADA) yang sebelumnya menjadi kompetensi Mahkamah Agung. Pengalihan wewenang konsekuensi dari ketentuan UU No.22 Tahun 2006 tentang penyelenggaraan Pemilu yang menempatkan PILKADA ke dalam rezim pemilihan umum.

Berkaitan dengan masalah kewenangan Mahkamah Konstitusi, secara panjang lebar Macfud M.D. dalam seminar Nasional di Fakultas Hukum Universitas Brawijaya, menulis:

1. berdasarkan wewenang yang dimiliki tersebut, Mahkamah Konstitusi merupakan pengawal konstitusi (the guardian of the constitution) terkait dengan empat wewenang dan satu kewajiban yang dimilikinya. Hal itu membawa konsekuensi Mahkamah Konstitusi berfungsi sebagai penafsir konstitusi (the sole interpreter of the constitution). Konstitusi sebagai hokum tertinggi mengatur penyelenggaraan Negara berdasarkan prinsip Negara demokrasi dan salah satu funsi konstitusi adalah melindungi hak asasi manusia yang dijamin dalam konstitusi sehingga menjadi hak konstitusional Warga Negara. Oleh karena itu Mahkamah Konstitusi juga berfungsi sebagai pengawal demokrasi (the guardian of the citizen's constitutional rights) serta perlindungan hak asasi manusia (the protector of human rights), ${ }^{26}$

2. reformasi hukum di Indonesia, merupakan prasyarat untuk menjadi Negara hukum yang demokratis. Bahwa prasyarat

${ }^{26}$ Lihat dalam "Enam Tahun Konstitusi dan Demokrasi, Gambaran Singkat Pelaksanaan Tugas Mahkamah Konstitusi 2003-2009”, Sekretariat Jenderal dan Kepaniteraan Mahkamah Konstitusi, Cetakan Pertama, (Jakarta: Konpress, tanpa tahun), hal. 13. 
terwujudnya masyarakat yang demokratis dalam prespektif negara hukum klasik salah satunya adalah adanya pembagian kekuasaan yang dapat menjamin kemerdekaan kekuasaan kehakiman. ${ }^{27}$ Langkah-langkah reformasi hukum tidak hanya dimulai dengan reformasi substansi hukum (legal substances) saja, seperti perbaikan kualitas perundang-undangan, dan peraturan-peraturan hukum lainnya, namun juga harus diikuti dengan perbaikan institusi kekuasaan kehakiman sebagai struktur hukum (legal structures);

3. meskipun demikian, tidak sedikit masyarakat yang sering terusik oleh putusan-putusan Mahkamah Konstitusi yang dipandang kontroversial, yakni putusan-putusan dalam pengujian UndangUndang yang bersifat ultapetita, bahkan ada kesan Mahkamah Konstitusi bukan hanya bertindak sebagai Negative Legislator tetapi juga sudah memasuki area positive legislator; ${ }^{28}$

4. pemberian kewenangan pengujian undang-undang kepada Mahkamah Konstitusi tanpa adanya pembatasan tertentu juga berpotensi terjadinya 'penyelewengan kekuasaan'. Bagaimana caranya membatasi kewenangan Mahkamah Konstitusi membatasi wewenang Mahkamah Konstitusi untuk pengujian undang-undang (Paasal 50), oleh Mahkamah Konstitusi Pasal tersebut telah 'diuji' sendiri karena dianggap bertentangan dengan UUD 1945. kalau demikian adanya, maka sesungguhnya tidak cukup kalau pembatasan kewenangan Mahkamah Konstitusi hanya diselesaikan melalui perubahan Undang-undang Mahkamah Konstitusi. Persoalan ini harus dibenahi, di tata ulang, dan disempurnakan melalui amandemen UUD 1945;

5. dalam putusan perkara 013-022/PUU-IV/2006, permohonan dikabulkan dan Pasal 134, Pasal 136 bis, serta Pasal 137 KUHP tentang penghinaan terhadap Presiden atau Wakil Presiden dinyatakan bertentangan dengan UUD 1945 dan tidak memiliki kekuatan hukum mengikat. Dalam perkara Nomor 6/PUU-

27 Bagir Manan, Hubungan Antara Pusat dan Daerah Berdasarkan Asas Desentralisasi Menurut UUD 1945, disertasi Doktor dalam Hukum Tata Negara, Fakultas Pascasarjana Universitas Padjajaran, Bandung, 1990, hal. 39. seperti yang dikutip oleh Mahfud MD. dalam "Politik Hukum Di Indonesia", Cetakan Ketiga, (Jakarta: LPEES, 2006), hal. 91.

${ }^{28}$ Misalnya dalam Putusan mahkamah Konstitusi No. 22-24/PUU-VI/2008 tentang Pemilu Anggota DPR, DPD, dan DPRD Berdasarkan Suara Terbanyak; Putusan Mahkamah Konstitusi No. 102/PUU-VII/2009 tentang Pilpre Boleh Memakai KTP atau paspor. 
V/2007, Mahkamah Konstitusi mengabulkan permohonan terhadap Pemerintah Republik Indonesia. MK berpendapat bahwa rumusan delik pada kedua pasal tersebut adalah delik formal sehingga menimbulkan kecenderungan penyalahgunaan kekuasaan secara mudah dapat ditafsirkan menurut selera penguasa. Dalam perkara Nomor 7/PUU-VI/2009, Mahkamah Konstitusi menyatakan bahwa pasal 160 KUHP konstitusional bersyarat, yaitu harus diberlakukan sebagi delik materiil sehingga harus ada tindak pedana yang disebabkan oleh penghasutan dimaksud;

6. Walaupun Mahkamah Konstitusi membatalkan ketentuanketentuan di atas atau menyatakankonstitusi bersyarat, namun putusan Mahkamah Konstitusi tidak berlaku surut. Artinya, terhadap vonis yang telah dijatuhkan pengadilan tetap harus dijalani pemohon, apalagi kalau pemohon sudah menjalani hukuman maka tidak ada pemulihan yang dapat dilakukan;

7. Mekanisme contitutional question disinggung dalam perkara 14/PUU-VI/2008, yang mengajukan pengujian terhadap Pasal 310 ayat (1) dan ayat (2), Pasal 311 ayat (1), Pasal 316, dan Pasal 207. Mahkamah Konstitusi berpendapat bahwa apa yang dialami oleh pemohon bukan merupakan persoalan norma, melainkan penerapan hukum yang sesungguhnya dapat diwadahi dalam mekanisme contitutional question atau contitusional complaint yang saat ini tidak dimiliki oleh Mahkamah Konstitusi;

8. untuk menerapkan mekanisme constitutional question tidak perlu dilakukan dengan Perubahan UUD 1945 guna menambahkan wewenang tersebut pada Mahkamah Konstitusi. Constitutional question sangat mungkin ditetapkan sebagai bagian dari wewenang MK menguji undang-undang terhadap UUD. Seorang hakim tentu dirugikan kewenangan konstitusionalnya untuk menegakkan hukum dan keadilan ika harus menerapkan suatu ketentuan undang-undang yang diragukan konstitusionalitasnya. Melalui mekanisme constitusional question dapat dihindarkan terjadinya ketidakadilan karena menjamin putusan hakim tidak melanggar hak konstitusional warga negara yang dijamin dalam UUD 1945 dan mencegah terjadinya ketidak pastian hukum karena adanya putusan hakim yang ternyata dikemudian hari ketentuan yang dijadikan dasar dibatalkan oleh Mahkamah Konstitusi.

Mahkamah Konstitusi dengan putusannya, adakalanya menimbulkan persoalan, terkait dengan eksistensi Mahkamah 
Konstitusi ini memamng ada persoalan, yakni adanya beberapa vonis Mahkamah Konstitusi yang dinilai melampaui batas kewenangan dan masuk ke ranah legislatif, padahal putusannya bersifat final dan mengikat. Selain itu, seperti disebutkan diatas, pengaturan konstitusi tentang pengujian peraturan perundang-undangan telah sedikit merancukan konsentrasi kekuasaan kehakiman dalam penanganan antara konflik peraturan dan konflik orang dan atau lembaga.

Mahkamah Konstitusi sering dinilai menjadikan dirinya sebagai lembaga yang super body sebab dengan selalu berlindung didalam ketentuan UUD bahwa putusannya bersifat final dan mengikat, lembaga ini adakalanya membuat putusan-putusan yang justru dapat di nilai melampaui kewenangan kontitusionalnya.oleh karena itu putusan Mahkamah Konstitusi seharusnya tetap dijaga agar dalam melaksanakan kewenangan selalu sesuai dengan maksud utama atau sesungguhnya (Original Intent), akan tetapi ada beberapa pendapat bahwa putusan-putusan Mahkamah Konstiusi yang adakalanya dianggap melampaui wewenangnya, seperti:

1. Putusan yang masuk ranah legislatif, karena bersifat mengatur;

2. Putusan yang mengeluarkan hakim-hakim Mahkamah Konstitusi dari obyek pengawasan Komisi Yudisial;

3. Putusan ang dianggap melanggar asas Nemo Judex In Causa Sua (larangan yang menyangkut dirinya sendiri);

4. Putusan yang mengatur pertentangan antara satu undang-undang dengan undang-undang lain, yang seharusnya vertikal (antara undang-undang dengan undang-undang dasar);

5. Putusan yang bersifat Ultra Petita (tidak diminta), sehingga mengarah ke ranah bidang legislatif.

Agar dalam melakukan kewenangannya dalam menguji undangundang terhadap UUD, MK tidak melampaui batas atau masuk ke ranah kekuasaan lain dan menjadi politis maka ada sepuluh dalam rumusan negatif (pelarangan) yang menurut penulis harus dijadikan rambu-rambu oleh Mahkamah Konstitusi, yaitu: ${ }^{29}$

1. dalam melakukan pengujian Mahkamah Konstitusi tidak boleh membuat putusan yang bersifat mengatur; pembatalan undangundang tak tidak boleh disertai pengaturan, misalnya dengan

${ }^{29}$ Sepuluh rambu ini hanya disampaikan di depan Komisi III-DPR-RIpada saat saya mengikuti fit and propertest untuk menjadi hakim konstitusi tanggal 12 Maret 2008. Ramburambu ini pernah saya tulis juga di dalam buku yang disiapkan untuk "mengatur purna tugas Prof. Dr. Maria Sumardjono," tanggal 2 Mei 2008 di Fakultas Hokum UGM, Yogyakarta. 
V/2007, Mahkamah Konstitusi mengabulkan permohonan terhadap Pemerintah Republik Indonesia. MK berpendapat bahwa rumusan delik pada kedua pasal tersebut adalah delik formal sehingga menimbulkan kecenderungan penyalahgunaan kekuasaan secara mudah dapat ditafsirkan menurut selera penguasa. Dalam perkara Nomor 7/PUU-VI/2009, Mahkamah Konstitusi menyatakan bahwa pasal 160 KUHP konstitusional bersyarat, yaitu harus diberlakukan sebagi delik materiil sehingga harus ada tindak pedana yang disebabkan oleh penghasutan dimaksud;

6. Walaupun Mahkamah Konstitusi membatalkan ketentuanketentuan di atas atau menyatakankonstitusi bersyarat, namun putusan Mahkamah Konstitusi tidak berlaku surut. Artinya, terhadap vonis yang telah dijatuhkan pengadilan tetap harus dijalani pemohon, apalagi kalau pemohon sudah menjalani hukuman maka tidak ada pemulihan yang dapat dilakukan;

7. Mekanisme contitutional question disinggung dalam perkara 14/PUU-VI/2008, yang mengajukan pengujian terhadap Pasal 310 ayat (1) dan ayat (2), Pasal 311 ayat (1), Pasal 316, dan Pasal 207. Mahkamah Konstitusi berpendapat bahwa apa yang dialami oleh pemohon bukan merupakan persoalan norma, melainkan penerapan hukum yang sesungguhnya dapat diwadahi dalam mekanisme contitutional question atau contitusional complaint yang saat ini tidak dimiliki oleh Mahkamah Konstitusi;

8. untuk menerapkan mekanisme constitutional question tidak perlu dilakukan dengan Perubahan UUD 1945 guna menambahkan wewenang tersebut pada Mahkamah Konstitusi. Constitutional question sangat mungkin ditetapkan sebagai bagian dari wewenang MK menguji undang-undang terhadap UUD. Seorang hakim tentu dirugikan kewenangan konstitusionalnya untuk menegakkan hukum dan keadilan ika harus menerapkan suatu ketentuan undang-undang yang diragukan konstitusionalitasnya. Melalui mekanisme constitusional question dapat dihindarkan terjadinya ketidakadilan karena menjamin putusan hakim tidak melanggar hak konstitusional warga negara yang dijamin dalam UUD 1945 dan mencegah terjadinya ketidak pastian hukum karena adanya putusan hakim yang ternyata dikemudian hari ketentuan yang dijadikan dasar dibatalkan oleh Mahkamah Konstitusi.

Mahkamah Konstitusi dengan putusannya, adakalanya menimbulkan persoalan, terkait dengan eksistensi Mahkamah 
Konstitusi ini memamng ada persoalan, yakni adanya beberapa vonis Mahkamah Konstitusi yang dinilai melampaui batas kewenangan dan masuk ke ranah legislatif, padahal putusannya bersifat final dan mengikat. Selain itu, seperti disebutkan diatas, pengaturan konstitusi tentang pengujian peraturan perundang-undangan telah sedikit merancukan konsentrasi kekuasaan kehakiman dalam penanganan antara konflik peraturan dan konflik orang dan atau lembaga.

Mahkamah Konstitusi sering dinilai menjadikan dirinya sebagai lembaga yang super body sebab dengan selalu berlindung didalam ketentuan UUD bahwa putusannya bersifat final dan mengikat, lembaga ini adakalanya membuat putusan-putusan yang justru dapat di nilai melampaui kewenangan kontitusionalnya.oleh karena itu putusan Mahkamah Konstitusi seharusnya tetap dijaga agar dalam melaksanakan kewenangan selalu sesuai dengan maksud utama atau sesungguhnya (Original Intent), akan tetapi ada beberapa pendapat bahwa putusan-putusan Mahkamah Konstiusi yang adakalanya dianggap melampaui wewenangnya, seperti:

1. Putusan yang masuk ranah legislatif, karena bersifat mengatur;

2. Putusan yang mengeluarkan hakim-hakim Mahkamah Konstitusi dari obyek pengawasan Komisi Yudisial;

3. Putusan ang dianggap melanggar asas Nemo Judex In Causa Sua (larangan yang menyangkut dirinya sendiri);

4. Putusan yang mengatur pertentangan antara satu undang-undang dengan undang-undang lain, yang seharusnya vertikal (antara undang-undang dengan undang-undang dasar);

5. Putusan yang bersifat Ultra Petita (tidak diminta), sehingga mengarah ke ranah bidang legislatif.

Agar dalam melakukan kewenangannya dalam menguji undangundang terhadap UUD, MK tidak melampaui batas atau masuk ke ranah kekuasaan lain dan menjadi politis maka ada sepuluh dalam rumusan negatif (pelarangan) yang menurut penulis harus dijadikan rambu-rambu oleh Mahkamah Konstitusi, yaitu: ${ }^{29}$

1. dalam melakukan pengujian Mahkamah Konstitusi tidak boleh membuat putusan yang bersifat mengatur; pembatalan undangundang tak tidak boleh disertai pengaturan, misalnya dengan

${ }^{29}$ Sepuluh rambu ini hanya disampaikan di depan Komisi III-DPR-RIpada saat saya mengikuti fit and propertest untuk menjadi hakim konstitusi tanggal 12 Maret 2008. Ramburambu ini pernah saya tulis juga di dalam buku yang disiapkan untuk "mengatur purna tugas Prof. Dr. Maria Sumardjono,” tanggal 2 Mei 2008 di Fakultas Hokum UGM, Yogyakarta. 
putusan pembatalan yang disertai dengan isi, cara, dalam lembaga yang harus mengatur kembali isi Undang-undang yang dibatalkan tersebut. Ini harus ditekankan karena bidang pengaturan adalah ranah legislatif. Jadi Mahkamah Konstitusi hanya boleh mengatur suatu Undang-undang yang dibatalkan tersebut. Jadi Mahkamah Konstitusi hanya boleh mengatakan suatu Undang-undang atau isinya konstitusional atau inkonstitusional yang disertai pernyataan tidak mempunyai kekuatan hukum mengikat;

2. dalam melakukan pengujian Mahkamah Konstitusi tidak boleh membuat ultra petita (putusan yang tidak diminta oleh pemohon) sebab dengan membuat ultra petita berarti Mahkamah Konstitusi mengintervensi ranah legislatif. Meski begitu ada juga yang berpendapat bahwa ultra petita boleh dilakukan oleh Mahkamah Konstitusi jika isi undang-undang dimintakan judicial review berkaitan langsung dengan pasal-pasal lain yang tidak bisa dipisahkan. Pemikiran seperti itu wajar tetapi bagi penulis sendiri kalau sebuah pasal undang-undang yang dimintakan uji materi ada kaitan dengan pasal-pasal lain yang tidak diminta untuk dibatalkan maka pembatalan tak bisa dilakukan atas pasal yang tidak diminta itu karenaitu dilakukan berarti merambah keranah legislatif. Bahwa pasal yang dibatalkan itu berkaitan dengan pasal lain, biarkanlah pembetulan/revisinya dilakukan oleh lembaga legislatif sendirti melalui legislative review. Toh, jika ada pasal di dalam undang-undang menjadi tidak berlaku karena ada pasal lain yang dibatalkan oleh Mahkamah Konstitusi dengan sendirinya pasal tersebut tak dapat dilaksanakan sehingga dengan sendirinya pula legislatif dituntut untuk melakukan legislative review; ${ }^{30}$

3. dalam membuat putusan Mahkamah Konstitusi tidak boleh menjadikan undang-undang sebagai dasar pembatalan undangundang lainnya. Tumpang tindih antar berbagai undang-undang menjadi kewajiban lembaga legislatif untuk menyelesaikannya melalui legislative review;

4. dalam membuat putusan Mahkamah Konstitusi tidak boleh mencampuri masalah-masalah yang didelegasikan oleh UUD kepada lebaga legislatif untuk mengaturnya dengan atau dalam

${ }^{30}$ Pada saat ini MK menyampaikan usul agar di dalam perubahan UUMK yang akan mulai dibahas bulan Juli 2008 masalah ultra petita itu dapat dimasukkan di dalam UUMK yang baru nanti sebagai kewenangan yang boleh dilakukan jika meteri yang di uji terkait langsung dengan materi lain yang ada di dalam UU tersebut. Jika benar nanti UUMK yang baru membolehkan MK membuat ultra petita, tentunya hal tersebut tidak dapat ditolak. 
undang-undang sesuai dengan pilihan politiknya sendiri. Apa yang diserahkan secara terbuka oleh UUD untuk diatur oleh undang-undang berdasar pilihan politik lembaga legislatif tidak bisa dibatalkan oleh Mahkamah Konstitusi kecuali jelas-jelas melanggar UUD 1945. didalam UUD 1945 sendiri banyak masalah yang diserahkan untuk diatur berdasar kebutuhan dan pilihan politik lembaga legislatif yang tentunya tidak dapat dicampuri oleh lembaga lain, temasuk oleh Mahkamah Konstitusi;

5. dalam membuat putusan Mahkamah Konstitusi tidak boleh mendasarkan pada teori yang tidak secara jelas dianut oleh konstitusi, sebab teori itu amat banyak dan bermacam-macam sehingga pilihan atas satu teori bisa bertentangan dengan pilihan atas teori lain yang sama jaraknya dengan UUD. Begitu juga, putusan Mahkamah Konstitusi tidak boleh didasarkan pada apa yang berlaku di negara-negara lain pun ketentuan konstitusinya dapat berbeda-beda. Oleh sebab itu yang harus menjadi dasar adalah isi UUD 1945 dan semua original intent-nya;

6. dalam melakukan pengujian Mahkamah Konstitusi tidak boleh melanggar asas nemo judex in causa sua, yakni memutus hal-hal yang berkaitan dengan kepentingan dirinya sendiri;

7. para hakim Mahkamah Konstitusi tidak boleh berbicara atau mengemukakan opini kepada publik atas kasus konkret yang sedang diperiksa Mahkamah Konstitusi, termasuk di seminarseminar dan pada pidato-pidato resmi. Ini penting agar dalam membuat putusan nantinya hakim Mahkamah Konstitusi tidak tersandera oleh pertanyaannya sendiri dan masyarakat pun tidak terpolarisasi oleh dugaan-dugaan tentang putusan yang dikeluarkan oleh Mahkamah Konstitusi

8. para hakim Mahkamah Konstitusi tidak boleh mencari-cari perkara dengan menganjurkan pada siapa pun untuk mengajukan gugatan atau permohonan ke Mahkamah Konstitusi. Biarlah yang mengambil inisiatif untuk itu justisiabelen sendiri;

9. para hakim Mahkamah Konstitusi tidak boleh secara proaktif menawarkan diri sebagai penengah dalam sidang sengketa politik antar lembaga negara atau antar lembaga-lembaga politik, sebab tindakan menawarkan diri itu sifatnya adalah politis, bukan legalistik. Mungkin menjadi penengah politik itu bertujuan baik, tetapi itu bukan ranah Mahkamah Konstitusi. Ada banyak lembaga lain yang lebih proposional untuk menengahi perseteruan politik melalui kerja-kerja politik. Biarkanlah dinamika politik bekerja, bergulat, dan selesai di ranahnya sendiri sesuai dengan 
peraturan perundang-undangan dari koridor-koridor etis yang tersedia;

10. MK tidak boleh ikut opini tentang eksistensi atau tentang baik atau buruknya UUD, atau apakah UUD yang sedang berlaku itu perlu diubah atau dipertahankan. Mahkamah Konstitusi hanya wajib melaksanakan atau mengawal UUD yang sudah ada dan berlaku sedangkan urusan mempertahankan atau mengubah adalah urusan lembaga lain yang berwenang. ${ }^{31}$

Kembali ke masalah apakah Mahkamah Konstitusi di Indonesia berwenang terhadap Contitusional Question? Secara konstitusional Mahkamah Konstitusi tidak berwenang, karena konstitusi tidak mengaturnya.

Akan tetapi beberapa catatan positif yang ada perlu untuk ditindak lanjuti seperti:

1. Putusan-putusan Mahkamah Konstitui yang ada, selalu mengacu pada garis yang telah dijadikan pedoman, seperti antara lain:

a. Sesuai alat bukti, minimal dua.

b. Putusannya memuat fakta, dasar hokum putusan,

c. Cara mengambil putusan secara demokratis berupa musyawarah mufakat, setiap hakim menyampaikan pendapat/ pertimbangan secara tertulis,

d. Bilan tidak tercapai kata mufakat diambil suara terbanyak dan suara terakhir ketua mmenentukan.

2. Putusan putusan Mahkamah konstitusi yang ada selama ini selalu diterima dengan dengan rasa puas dan dianggap mencerminkan keadilan bagi masyarakat luas.

3. Putusannya selalu mendasarkan pada ketentuan undang-undang, khususnya Undang-Undang No.24 Tahun 2003, tentang Mahkamah Konstitusi Pasal 45 Ayat (1): Mahkamah Konstitusi memutus perkara berdasarkan Undang-undang Dasar Negara Republik Indonesia sesuai dengan alat bukti dan keyakinan hakim.

31 Tentu saja untuk keperluan akademik hal ini diperbolehkan, misalnya untuk perkuliahan dan seminar-seminar yang murni akademis, bukan opini politis. 


\section{Penutup}

\section{A. Kesimpulan}

1. Secara normatif sebagaimana ketentuan dalam Kitab UndangUndang Hukum Pidana (KUHP) pasal 504 ayat (1) dan (2), yang intinya bahwa meminta-minta (mengemis) di muka umum dapat dihukum karena meminta-minta, dengan hukuman selama enam minggu dan bila perbuatan itu dilakukan secara bersama-sama dilakukan lebih dari tiga orang berumur di atas enam belas tahun dihukum dengan kurungan selama tiga bulan. Karena normanya mengatur demikian, maka sifat yang imperative/harus dilaksanakan.

Bagi anak-anak muda, remaja, generasi penerus yang baik sendirisendiri maupun bersama sama dengan memakai gerak gerik menjual lagu dengan jalan menyanyi dengan memainkan alat musik seperti gitar, meminta-minta dari rumah ke rumah atau di jalanan adalah melanggar KUHP dan dapat dihukum.

2. Setiap orang berkeinginan hidup yang layak yang menurut konstitusi Undang-Undang Dasar Negara Republik Indonesia tahun 1945 pada bab X tentang Hak asasi Manusia, khususnya pasal 28 A yang menyebutkan bahwa Negara menjamin bagi setiap warganegaranya untk berhak hidup serta mempertahankan hidup dan kehidupannya.

Dinyatakan pula bahwa setiap orang berhak utuk hidup sejahtera lahir batin, bertempat tinggal dan mendapat lingkungan hidup yang baik dan sehat serta berhak memperoleh pelayanan kesehatan. Jelas di sini secara konstitusional Negara dalam hal ini pemerintah menjamin keberadaan warga negaranya, sehingga apabila terdapat warganegara masyarakat di Republik tercinta ini hidup dengan meminta-minta jelas tidak sejalan dengan makna konstitusi yang ada.

Lebih tegas lagi bahwa konstitusi kita menyebutkan bahwa Negara menjamin kehidupan warga negaranya, dan mempunyai tanggungjawab agar hidup yang layak, adalah wajar apabila konstitusi kita dalam batang tubuhnya (pasal 34 ayat (1)), menyebutkan "Fakir miskin dan anak anak terlantar dipelihara oleh Negara.

Dengan demikian secara normative soal meminta-minta "pengemis" dapat dinyatakan dilarang bertentangan dengan hukum positif yang ada (KUHP), akan tetapi sebaliknya secara 
konstitusional Negara mempunyai tanggungjawab untuk mengentaskan kemiskinan yang ada.

Dari uraian di atas, jelas ketentuan norma hukum tentang "pengemis" dalam pasal 504 ayat (1) dan (2) dilarang, sebaliknya "pengemis" harus tidak ada, sebagaimana disebutkan dalam konstitusi Negara dan menjadi tanggungjawab Negara, dari kesimpulan tersebut maka, hakim sang pengadil dalam memeriksa perkara tersebut menjadi dilematis, sehingga dapat mengajukan pertanyaan konstitusi atau Constitutional Question.

3. Mahkamah Konstitusi merupakan the guardian of the contitution, sebagaimana ditentukan dalam UUD NRI Tahun 1945, memiliki empat kewenangan yang sudah digariskan yaitu: menguji undangundang terhadap Undang-Undang Dasar, memutus sengketa kewenangan lembaga Negara, memutus pembubaran partai politik, memutus perselisihan hasil pemilu dan memberi putusan mengenai dugaan pelanggaran oleh Presiden serta memeriksa dan memutus sengketa pemilihan kepala daerah.

Dalam kehidupan berbangsa dan bernegara dan sebagai pengawal konstitusi dengan wewenang-wenang yang ada dan kewajiban yang dimiliki, maka Mahkamah Konstitusi berfungsi sebagai penafsir konstitusi. Konstitusi sebagai dasar Negara, the higher law of the land, mengatur penyelenggaraan Negara berdasar prinsip Negara demokrasi yang salah satu fungsinya adalah melindungi hak asasi manusia yang dijamin dalam konstitusi, sehingga menjadi hak konstitusional warganegara.

Menyoal "pengemis" atau peminta-minta di jalan yang secara sepihak menurut ketentuan (KUHP) dilarang di pihak lain secara konstitusional (UUD N RI Tahun 1945) menjadi tanggungjawab Negara dan terkait erat dengan hak asasi manusia.

Adanya pertanyaan konstitusi (Constitutional Question) dari hakim yang mengadili "pengemis", sekalipun pengemis terkait dengan masalah hak asasi manusia, Mahkamah konstitusi di Indonesia tidak berwenang terhadap Constitusional Question, karena wewenang Mahkamah Konstitusi sudah tercantum sebagaimana ketentuan yang ada.

\section{B. Saran.}

Kemajuan Negara yang ada utamanya pengaruh globalisasi, perkembangan hukum yang kompleks beserta kemajuan teknologi dan pola pikir manusia, sedangkan hukum yang masih serba konstan, yang 
berkutat dengan tulisan yang apa adanya. Maka sejogyanya dibuka kran bagi Mahkamah Konstitusi berkaitan dengan adanya pertanyaan Konstitusi (Constitustional Question), dengan jalan merubah UUD N RI Tahun 1945, yang salah satunya menambah kewenangan Mahkamah Konstitusi yang ada.

Dalam kaitan itu, sebagai penutup tulisan ini, kiranya kutipan kata-kata mantan Hakim Agung Amerika, Judge Learned Hand berikut ini dapat lebih meyakinkan kita akan pentingnya kesadaran berkonstitusi itu:

I often wonder whether we do not rest our hopes too much upon contitutions, upon laws and upon courts. These are false hopes; belive me, these are false hopes. Liberty lies in the hearts of men and women; when is dies there, no constitution, no law, no court can save it; no constitution, no law, no court can even do much to help it. While if it lies there it needs no constitution, on law, no court to save it.

(Saya kerap merenung jangan-jangan kita telah menaruh harapan terlalu besar pada konstitusi, pada hukum, dan pada pengadilan. Ini hanyalah harapan semu; percayalah, ini hanya harapan semu.kebebasan sejati bersemayam di hati setapa laki-laki dan perempuan; tatkala disitu ia mati, tidak ada konstitusi, tidak ada hukum, tidak ada pengadilan yang mampu menyelamatkannya; bahkan tak banyak yang dapat diperbuat oleh konstitusi, hukum, pengadilan untuk menolongnya. Namun selama kebebasan bersemayam di hati setiap laki-laki dan perempuan, ia tidak membutuhkan konstitusi, ia tidak membutuhkan hukum, ia tidak membutuhkan pengadilan guna menyelamatkannya). 


\section{Daftar Pustaka}

Asshiddiqie, Jimly. Model-Model Pengujian Konstiusional di Berbagai Negara, Cetakan Kedua, Jakarta: Konpres, 2005.

Comelia, Victor Ferreres. "Is The European Model of Constitutional Review in Crisis", paper presented for the 12 th Annual Conference on The Individual Vs the State, Budapest: Central European University, June 18-192004.

Friedman, Lawrence M. The Republic of Chice, Law, Authority, and Culture, Harvard University Press, 1990.

Hawwa, Sa'id. Hadist Shahih Intisari Ihya'Ulumudin Al Ghazali, Mensucikan Jiwa Konsep Tazkiyatum-Hafs Terpadu, Jakarta: Robbani Press, 1998.

Hausmaninger, H. The Austrian Legal System, Wien: Manzsche Verlags- und Universitatsbuchhandlung, 2003.

Huda, Ni'matul. “Perkembangan Peran Mahkamah Konstitusi Dalam upaya menegakan Hukum dan Keadilan", disampaikan dalam acara Seminar Sehari Mekanisme Constitutional Question Sebagai Sarana Menjamin Supremasi Konstitusi, diselenggarakan oleh Pusat Pengkajian Konstitusi Fakultas Hukum Universitas Brawijaya kerjasama dengan Sekretariat Jenderal dan Kepaniteraan Mahkamah Konstitusi RI, Malang 21 November 2009.

Kommers, Donald P. The Constitutional Jurisprudence of the Federal Republic of Germany, Durham and London: Duke University Press, 1989.

M.D., Machfud. disampaikan dalam acara Seminar Sehari Mekanisme Constitutional Question Sebagai Sarana Menjamin Supremasi Konstitusi, diselenggarakan oleh Pusat Pengkajian Konstitusi Fakultas Hukum Universitas Brawijaya kerjasama dengan Sekretariat Jenderal dan Kepaniteraan Mahkamah Konstitusi RI, Malang 21 November 2009.

Makagiansar, Makaminam. pidato dalam "Thrid Annual Meeting of Asean Acendemies of Science" Engineering and Technology and Similar National, Manila Philippnes, July 8-9, 1999.

Manan, Bagir. "Hubungan Antara Pusat dan Daerah Berdasarkan Asas Desentralisasi Menurut UUD 1945", disertasi Doktor dalam Hukum Tata Negara, Fakultas Pascasarjana Universitas Padjajaran, Bandung, 
1990, seperti yang dikutip oleh Mahfud MD, dalam "Politik Hukum Di Indonesia, Cetakan Ketiga, Jakarta: LPEES, 2006.

Nusantara, Abdul Hakim Garuda. Mahkamah Konstitusi Perspektif Politik dan Hukum, Harian Kompas, 24 September 2002.

Schur, Edwin M. Law and Society, A Sociological Perspectif. New York: Random House, 1968.

Schwartz, Herman. The Struggle for Constitutional Justice in Post Communist Europe, Chicago and London: The University of Chicago Press, 2000.

Soehino, Ilmu Negara. Yogyakarta: Liberty, 1980.

Indonesia, Undang Undang Dasar 1945.

Kitab Undang-Undang Hukum Pidana. 